\title{
The incorporation of the study into water consumption in energy audits in schools
}

\section{La incorporación del estudio del consumo de agua en las auditorías energéticas de los centros docentes}

Jorge Gallego Sánchez-Torija (Main and Corresponding Author)

Escuela Técnica Superior de Arquitectura, Universidad Politécnica de Madrid

Avenida Juan de Herrera, 4. 28040 Madrid (Spain)

jorge.gallego@upm.es

\section{Enrique Larrumbide Gómez-Rubiera}

Escuela Técnica Superior de Arquitectura, Universidad Politécnica de Madrid

Avenida Juan de Herrera, 4. 28040 Madrid (Spain)

enrique.larrumbide@upm.es

\section{César Bedoya Frutos}

Escuela Técnica Superior de Arquitectura, Universidad Politécnica de Madrid Avenida Juan de Herrera, 4. 28040 Madrid (Spain)

cesar.bedoya@upm.es

Manuscript Code: 652

Date of Acceptance/Reception: 15.08.2017/17.06.2016

DOI: 10.7764/RDLC.16.3.361

\begin{abstract}
The approach of energy audits usually disregards the study of water as it considers that the supply does not involve energy consumption within the building. This paper aims to make visible both the energy footprint involved in ensuring safe water for human consumption and the collection and treatment of waste water. Furthermore, a methodology for conducting an energy audit is shown for the study of water consumption and applies it to a school to verify whether the measures proposed to reduce the consumption of water and the energy associated to it are viable. A school is chosen for three reasons. It is medium sized so the results can be extrapolated to other buildings. It presents a relevant water consumption due to the number of users, but without it being as high as a swimming pool might be. Finally it does not have a water heating system (there are no showers in the gym) so it only studies the energy consumption associated with drinking water without incorporating the effects of energy consumption for water heating.
\end{abstract}

Key words: Water, energy audit, energy efficiency, sustainability, school.

\section{Resumen}

El planteamiento de las auditorías energéticas al uso habitualmente prescinde del estudio del agua al considerar que dicho suministro no conlleva un consumo de energía dentro del edificio. El presente trabajo pretende visibilizar la huella energética que supone disponer de agua apta para el consumo humano así como la recogida y tratamiento de las aguas una vez han sido usadas. Adicionalmente se muestra una metodología para la realización de la auditoría energética en cuanto al estudio del consumo de agua se refiere y se aplica a un centro docente para verificar si las medidas que se proponen para reducir el consumo de agua y de energía asociado al mismo son viables. Se escoge un centro docente para el estudio por tres motivos: tiene un tamaño medio por lo que sus resultados son extrapolables a otros edificios; presenta un consumo de agua significativo debido al número de usuarios, pero sin resultar tan elevado como pudiera ser una piscina; finalmente, no dispone de instalación de calentamiento de agua (no hay duchas en el polideportivo) por lo que se puede estudiar exclusivamente el consumo de energía asociado al consumo de agua sin incorporar los efectos del consumo energético para calentar el agua.

Directive 2012/27/EU defines the term energy audit as:

"Any systematic procedure to obtain adequate knowledge of the profile of the existing energy consumption of a building or group of buildings, of an installation or industrial or commercial operation, or a private or public service, and to identify and quantify possibilities of saving energy at an efficient cost and report on it" (Parlamento Europeo, 2012).

The rational use of energy in buildings involves improving the energy efficiency of a complex building-manenvironment system, achieving equal or better environmental quality with lower use of energy resources (Evans \& Schiller, 2007). 
The process involves understanding the building in metabolic balance with the natural environment and inhabited by people involved in this metabolism seeking to achieve an hygrothermal comfort (Granero \& García, 2013).

\section{Problem Description}

Water as an economic asset, of which proper management is paramount. Users currently pay a price for their domestic consumption that does not reflect the total expense of its complete cycle. In Spain the water supply is guaranteed at the moment. Only in certain periods of drought are restrictions on consumption imposed, mainly associated with irrigation. However climate change may lead to further desertification in the country whose consequences for water management are unknown.

Worldwide, the problem is quite different: the global water crisis in the "water planet" (Arrojo, 2013). Not only it is due to its scarcity but inequality generates poverty and misguided policies in its management. It is often said that future wars will be over water, an economic asset essential to survival. Currently it is estimated that one billion people do not have guaranteed access to drinking water which, according to the United Nations, gives rise to about ten thousand deaths a day.

\section{Background}

Several authors have considered the importance of the relationship between water consumption and associated energy consumption.

Energy is consumed at every stage of the cycle of water supply, treatment, use and disposal. The intensity of energy consumption $\left(\mathrm{kWh} / \mathrm{m}^{3}\right)$ depends on the specific technologies applied at each stage of the water cycle (Plappally \& Lienhard, 2012). Water-related energy and related greenhouse gas emissions are important issues in future cities (Kenway, McMahon, Elmer, Conrad \& Rosenblum, 2013). Water energy nexus is an issue of increasing importance (Gómez, Cabrera, Balaguer \& Soriano, 2015). Resource attributes of water and energy along with the large infrastructure systems conventionally used to source, transport, and distribute them, plus the recovery of waste, make water and energy core resources to take into consideration for urban planning in a nexus framework (Scott, Crootof \& Kelly-Richards, 2016).

As regards the relationship between water and energy, water consumption in buildings is not normally within the scope of energy audits, or the diagnosis and energy characterizations (Arco et al., 2013). This is because the utilization of water is a negligible energy consumption in the building itself, except the consumption of electricity by the water pump where appropriate. Only the energy consumption study used for raising the temperature of hot water is taken into account.

However the ultimate triple goal of energy audits for states is to improve energy security, help reduce emissions of greenhouse gases and achieve an improvement from the economic point of view. To achieve these objectives, it is not relevant that the reduction in energy consumption takes place within the building itself or in infrastructures that provide the service.

For the manager of the building, it is also beneficial to extend the scope of strict energy consumption within the building. This is an accounting concept that is included within the supplies and whose consumption is likely to be more efficient, meaning cost savings.

We must also not forget that having water available simply by opening a faucet in a building implies the consumption of energy. Traditionally, water has been used as a source of energy production in wells and windmills and later with the advent of the turbines in hydroelectric plants. Urban drinking water and the subsequent treatment of the wastewaters currently consumes power. $30 \%$ of spending on the integrated water cycle corresponds to energy, and it is estimated at nearly $16 \%$ of total energy consumption in Spain (Martín, 2014).

There is still no comprehensive study to determine the energy consumption of the water cycle in Spain. Some authors claim that if energy consumption completed in the process of wastewater purification, added to the energy consumed in the transport of that water, in the urban distribution of drinking water and its catchment, the average number is 3 $\mathrm{kWh} / \mathrm{m}^{3}$ (Cabrera, Pardo, Cabrera \& Cobacho, 2010; Martín, 2014). But if the water supply comes from a desalination plant, the energy consumption amounts to $7.74 \mathrm{kWh} / \mathrm{m}^{3}$ (Martínez, 2011). 
This data is higher than data obtained in Mexico City of $1.32 \mathrm{kWh} / \mathrm{m}^{3}$ (Centro Mario Molina, 2011). Although it should be noted that this value varies depending on the origin of water from between $0.253 \mathrm{kWh} / \mathrm{m}^{3}$ and $4.541 \mathrm{kWh} / \mathrm{m}^{3}$.

Energy consumption in water supplied and wastewater treated in Spain is similar to energy consumption in Southern California: $2.9 \mathrm{kWh} / \mathrm{m}^{3}$ (California Energy Commission, 2006), and in Germany: $2.69 \mathrm{kWh} / \mathrm{m}^{3}$ (Hardi \& Garrido, 2010), although it differs from energy consumption in Northern California: $0.9 \mathrm{kWh} / \mathrm{m}^{3}$ (California Energy Commission, 2006), and Oslo: $1.25 \mathrm{kWh} / \mathrm{m}^{3}$ (Venkatesh \& Bratteb $\varnothing, 2011$ ).

For this reason it is considered appropriate to include the study of water consumption as part of the energy audit.

Methodology

\section{Data collection}

The energy auditor collects the following data in collaboration with the organization:

- Contracting: water supply company and contractual conditions.

- Consumption: evolution of the different consumption variables over the last 5 consecutive years available.

- Cost of the different concepts billed and its evolution over the past 5 consecutive years available.

- History of past operations and events that may have affected the water consumption in the period covered by the data collected.

- Available documentation design, operation and maintenance.

\section{Field work}

During the site visit the energy auditor carries out the following actions and collects the following data:

- The list of equipment using water.

- The technical specifications of each piece of equipment using water: types of faucets and toilets and brand and model of the domestic appliances.

- The instantaneous flow rate of each faucet. To achieve this, a one liter capacity container will be provided and the filling time will be measured. Then the inverse of the measured time will be found and the resulting value will be the instantaneous flow rate of the faucet in liters per second.

- Volume of toilet tank by measuring its dimensions to find the water consumption for each flush.

- Inspection of general plumbing installation.

- Ask the person responsible for maintenance of the facility about changes made to the plumbing, operating routines and users behavior.

\section{Billing analysis}

The consumption data collected from the bills during the last five years are drawn up to obtain the following aims:

- Estimate the consumption of bills that have not been provided because they have gone astray, carrying out an average of the collected consumption within the same period.

- Replace the consumption which has a large deviation from the average data due to water leaks by the mean values within the same period to not distort consumption that occurs in the normal use of the installation, and discarding the influence in this consumption from specific installation breaks.

Graphically and tabulated data are presented, showing the average consumption of each billing period and the total consumption of each year and the average annual water consumption.

To make the data comparable to water consumption with other buildings of similar characteristics, the following indicators are calculated:

- Annual water consumption by area $\left(\mathrm{m}^{3} / \mathrm{m}^{2}\right)$

- Annual water consumption per user ( $\mathrm{m}^{3} / \mathrm{user}$ )

- Daily water consumption per user (I/user) 
The values of the indicators obtained with the benchmarks are compared. The average water consumption in Spanish schools is 4.7 liters per user per day (Barón \& González, 2003).

Then the following indicators of $\mathrm{CO}_{2}$ emissions associated with water consumption are quantified:

- Annual $\mathrm{CO}_{2}$ emissions ( $\mathrm{t}$ )

- Annual $\mathrm{CO}_{2}$ emissions per user ( $\left.\mathrm{kg} / \mathrm{user}\right)$.

The applied coefficient per passage is $0.331 \mathrm{kgCO}_{2} / \mathrm{kWh}$, extracted from the document recognized for the justification of compliance with Spanish regulations (Ministerio de Industria, Energía y Turismo \& Ministerio de Fomento, 2014), which is applied to an energy consumption of $3 \mathrm{kWh} / \mathrm{m}^{3}$, gives a value of 0.993 emissions of $\mathrm{CO}_{2}$ per $\mathrm{kWh}$.

Finally the following economic indicators associated to water consumption are shown:

- Annual water consumption bill (€)

- Annual water consumption bill per user (€/user)

- Rates for water consumed $\left(€ / \mathrm{m}^{3}\right)$

\section{Distribution of water consumption}

A distribution of water consumption between the various existing consumer equipment is established in the building. We proceed as follows:

- The average consumption of the toilets for each use is determined.

- The average flow of the faucets is determined.

- The number of daily toilet uses for each user of the building is estimated taking into account the number of hours it is in use.

- The number of daily uses of washbasin per user of the building and the average time of each use are estimated, considering the number of hours it is in use.

- The ratio of liters of water per $\mathrm{m}^{2}$ for cleaning the building is estimated.

- The ratio of liters of water for each meal that takes place in the school canteen is estimated.

- The daily consumption is multiplied by the number of days when the school is open to find the annual consumption of each system.

- Check that the overall result is set to the average consumption obtained from billing data. The corresponding adjustment of earlier estimates are made, considering the small differences that may exist as consumption carried out by other causes such as sinks in laboratories or small leaks in the plumbing.

- The corresponding economic cost is associated to each area of consumption.

The water consumption distribution data obtained allows to use in each proposal the consumption carried out in the equipment in which it is studied to implement the proposal.

The present study does not contemplate the implantation of pressure reducing valves, due to the fact that a building with a low height is used in the case study. This means that there is no excess pressure in the lower floors, in order to supply water with adequate pressure in the upper floors. On the other hand, as it is a building with an important extension in the plant, the plumbing distribution network has an important horizontal branch on the ground floor with its corresponding mounts for wet rooms.

Case study results

The case study is the Calasanz school which is located at number 29, Santiago Street in Alcalá de Henares, Madrid, Spain. The school is made up of 5 buildings:

1. Infant school building.

2. Infant and first-year primary building.

3. Second- and third-year primary building and Information and communications technology (ICT) building.

4. Secondary education and advanced level building.

5. Common areas and intermediate vocational training building. 
Its surface is $6,500 \mathrm{~m}^{2}$ and it has 1,030 students.
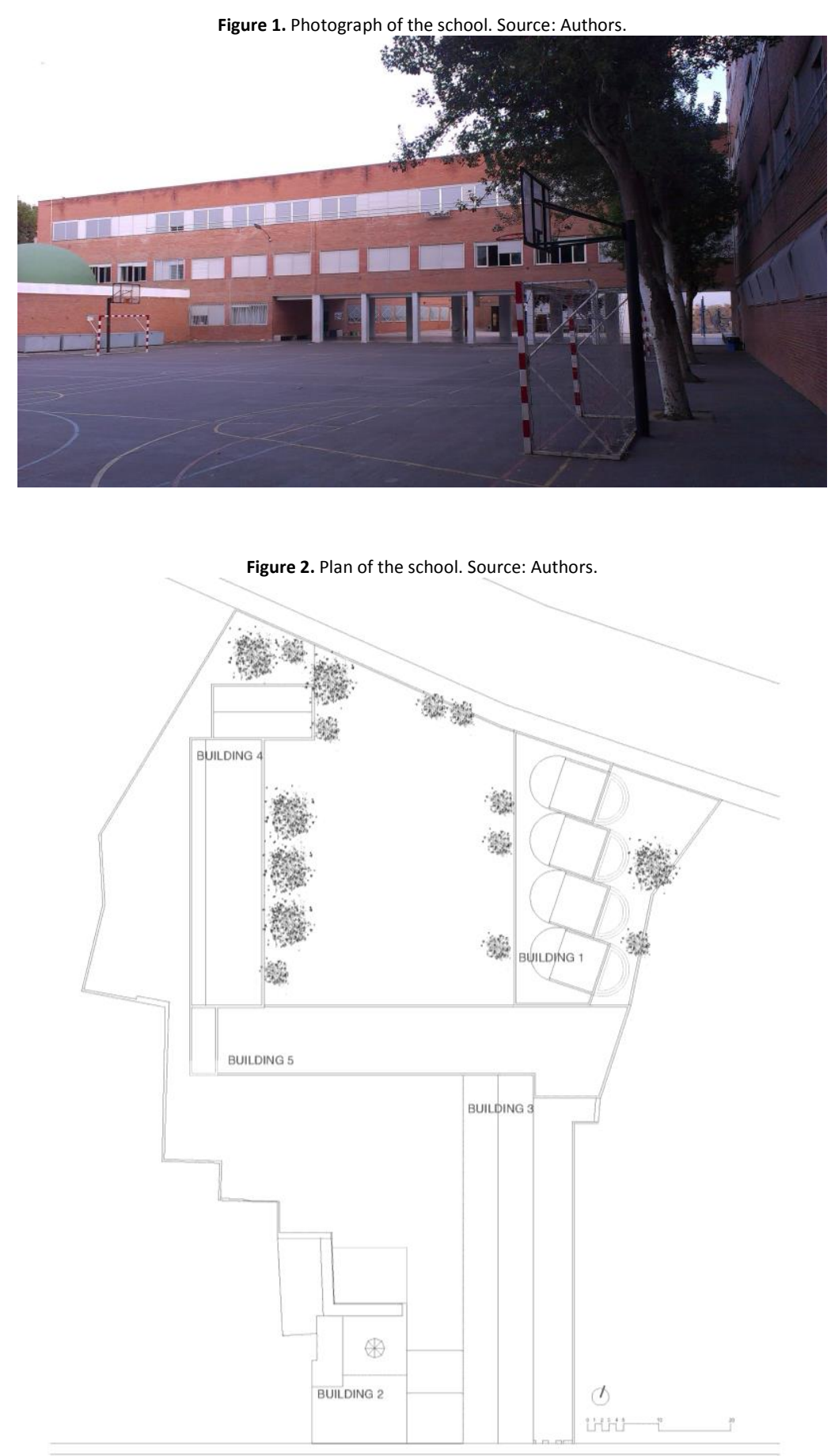

\section{Description of water consumption equipment}

The water consumption points in the educational institution are as follows:

Below is a list of the existing toilets in the building and their types. Note that most are high wall-mounted cistern to avoid problems arising from users' access to tanks. The existing toilets in Building 2 produce the water discharge through a flush valve. In these devices water is consumed only while holding the handle/button down, which is positive from the viewpoint of water consumption. They only use the water needed and they close when the user releases the handle/button. 


\begin{tabular}{|c|c|c|c|c|c|}
\hline & Washbasin & Toilet & Sink & $\begin{array}{l}\text { Waste } \\
\text { basin }\end{array}$ & Others \\
\hline \multicolumn{6}{|l|}{ Building 1} \\
\hline Ground Floor & 4 (single) & $\begin{array}{l}4 \text { (high wall- } \\
\text { mounted cistern) }\end{array}$ & - & 1 & - \\
\hline \multicolumn{6}{|l|}{ Building 2} \\
\hline Ground Floor & - & - & - & - & $\begin{array}{l}1 \text { washing } \\
\text { machine }\end{array}$ \\
\hline $1^{\text {st }}$ Floor & 3 (single) & 5 (flush valve) & - & 1 & - \\
\hline $2^{\text {nd }}$ Floor & 2 (single) & 4 (flush valve) & - & 1 & - \\
\hline \multicolumn{6}{|l|}{ Building 3} \\
\hline Ground Floor & 3 (timed) & $\begin{array}{l}6 \text { (high wall- } \\
\text { mounted cistern) }\end{array}$ & - & 1 & - \\
\hline \multicolumn{6}{|l|}{ Building 4} \\
\hline Ground Floor & - & - & 2 & - & $\begin{array}{l}\text { 1dish- } \\
\text { washer }\end{array}$ \\
\hline $1^{\text {st }}$ Floor & 4 (timed) & $\begin{array}{l}6 \text { (high wall- } \\
\text { mounted cistern) }\end{array}$ & - & 1 & - \\
\hline $2^{\text {nd }}$ Floor & 5 (timed) & $\begin{array}{l}7 \text { (high wall- } \\
\text { mounted cistern) }\end{array}$ & - & 1 & - \\
\hline $3^{\text {th }}$ Floor & 5 (timed) & $\begin{array}{l}7 \text { (high wall- } \\
\text { mounted cistern) }\end{array}$ & - & 1 & - \\
\hline \multicolumn{6}{|l|}{ Building 5} \\
\hline Ground Floor & $\begin{array}{l}4 \text { (timed) } \\
2 \text { (mono- } \\
\text { faucet) }\end{array}$ & $\begin{array}{l}8 \text { (high wall- } \\
\text { mounted cistern) }\end{array}$ & & 1 & $\begin{array}{l}1 \text { dish- } \\
\text { washer }\end{array}$ \\
\hline $1^{\text {st }}$ Floor & 9 (timed) & $\begin{array}{l}11 \text { (high wall- } \\
\text { mounted cistern) }\end{array}$ & 2 & 2 & $\begin{array}{l}20 \text { wash } \\
\text { basins }\end{array}$ \\
\hline $2^{\text {nd }}$ Floor & 9 (timed) & $\begin{array}{l}11 \text { (high wall- } \\
\text { mounted cistern) }\end{array}$ & 1 & 2 & - \\
\hline $3^{\text {th }}$ Floor & 4 (timed) & $\begin{array}{l}6 \text { (high wall- } \\
\text { mounted cistern) }\end{array}$ & - & 1 & - \\
\hline TOTAL & 54 & 75 & 5 & 13 & \\
\hline
\end{tabular}

Table 2. List of the existing toilets in the building and their types. Source: internal document.

\begin{tabular}{|c|c|c|c|c|c|c|c|}
\hline \multirow{2}{*}{$\begin{array}{l}\text { Toilets } \\
\text { Building } 1\end{array}$} & \multirow[b]{2}{*}{ Ground Floor } & \multirow{2}{*}{$\frac{\text { Number }}{4}$} & \multirow{2}{*}{\begin{tabular}{l}
\multicolumn{1}{c}{ TYPE } \\
High wall-mounted \\
cistern
\end{tabular}} & \multicolumn{3}{|c|}{ Dimensions $(\mathrm{cm})$} & \multirow{2}{*}{$\begin{array}{c}\begin{array}{c}\text { Discharge volume } \\
\text { (I) }\end{array} \\
8.7\end{array}$} \\
\hline & & & & 34 & 16 & 26 & \\
\hline \multirow[t]{2}{*}{ Building 2} & $1^{\text {st }}$ Floor & 5 & Flush valve & - & - & - & 4.8 \\
\hline & $2^{\text {nd }}$ Floor & 4 & Flush valve & - & - & - & 4.8 \\
\hline Building 3 & Ground Floor & 6 & $\begin{array}{l}\text { High wall-mounted } \\
\text { cistern }\end{array}$ & 33 & 16 & 23 & 7.5 \\
\hline \multirow[t]{3}{*}{ Building 4} & $1^{\text {st }}$ Floor & 6 & $\begin{array}{l}\text { High wall-mounted } \\
\text { cistern }\end{array}$ & 36 & 19 & 34 & 14.7 \\
\hline & $2^{\text {nd }}$ Floor & 7 & $\begin{array}{l}\text { High wall-mounted } \\
\text { cistern }\end{array}$ & 36 & 19 & 34 & 14.7 \\
\hline & $3^{\text {th }}$ Floor & 7 & $\begin{array}{l}\text { High wall-mounted } \\
\text { cistern }\end{array}$ & 36 & 19 & 34 & 14.7 \\
\hline \multirow[t]{4}{*}{ Building 5} & Ground Floor & 8 & $\begin{array}{l}\text { High wall-mounted } \\
\text { cistern }\end{array}$ & 34 & 16 & 26 & 8.7 \\
\hline & $1^{\text {st }}$ Floor & 11 & $\begin{array}{l}\text { High wall-mounted } \\
\text { cistern }\end{array}$ & 34 & 16 & 26 & 8.7 \\
\hline & $2^{\text {nd }}$ Floor & 11 & $\begin{array}{l}\text { High wall-mounted } \\
\text { cistern }\end{array}$ & 34 & 16 & 26 & 8.7 \\
\hline & $3^{\text {th }}$ Floor & 6 & $\begin{array}{l}\text { High wall-mounted } \\
\text { cistern }\end{array}$ & 34 & 16 & 26 & 8.7 \\
\hline TOTAL & & 75 & & & & & 9.8 \\
\hline
\end{tabular}


Below is a list of existing wash basins in the building with the main features of their fittings. Note that the toilets are intended solely for the consumption of cold water.

Table 3. List of existing toilets in the building and the type of their faucets. Source: internal document.

\begin{tabular}{llclcc}
\hline \multicolumn{2}{c}{ Washbasin } & Number & Faucet type & Flow (I/min) & Closing time (s) \\
\hline Building 1 & Ground Floor & 4 & Single & 7.6 & - \\
Building 2 & $1^{\text {st }}$ Floor & 3 & Single & 20.0 & - \\
Building 3 & $2^{\text {nd }}$ Floor & 2 & Single & 12.5 & - \\
& Ground Floor & 3 & Timed & 10.3 & 8 \\
Building 4 & $1^{\text {st }}$ Floor & 4 & Timed & 5.8 & 8 \\
& $2^{\text {nd }}$ Floor & 5 & Timed & 1.7 & 12 \\
& $3^{\text {th }}$ Floor & 5 & Timed & 7.1 & 12 \\
& Ground Floor & 4 & Timed & 4.7 & 12 \\
Building 5 & $1^{\text {st }}$ Floor & 2 & Mono-faucet & 19.4 & - \\
& $2^{\text {nd }}$ Floor & 9 & Timed & 5.9 & 12 \\
TOTAL & $3^{\text {th }}$ Floor & 9 & Timed & 7.4 & 10 \\
\hline
\end{tabular}

\section{Billing analysis}

The billing information is collected from the last 5 years. The water consumption data can be seen in the table below:

\begin{tabular}{lcccccc}
\hline & \multicolumn{7}{c}{ Table 4. Water consumption data for five years. Source: internal document. } \\
\cline { 2 - 7 } Month & 2013 & 2012 & 2011 & 2010 & 2009 & Average \\
\hline February & 700 & 499 & 562 & 454 & 579 & 559 \\
April & 321 & 672 & 547 & 511 & 502 & 511 \\
June & 338 & 695 & 502 & 530 & 420 & 497 \\
August & 231 & 231 & 242 & 242 & 239 & 237 \\
October & 500 & 390 & 322 & 305 & 112 & 326 \\
December & 312 & 534 & 402 & 500 & 388 & 427 \\
TOTAL & 2,402 & 3,021 & 2,577 & 2,542 & 2,240 & 2,556 \\
\hline
\end{tabular}

To make the water consumption data comparable with other buildings of similar characteristics, indicators of annual water consumption by surface, annual water consumption per user and the daily water consumption per user are obtained.

Table 5. Indicators of annual surface water consumption, annual water consumption per user and daily water consumption

\begin{tabular}{lcccccc}
\multicolumn{7}{c}{ per user for 5 years. Source: internal document. } \\
\hline & 2013 & 2012 & 2011 & 2010 & 2009 & AVERAGE \\
\hline $\begin{array}{l}\text { Anual water consumption } \\
\text { per area }\left(\mathrm{m}^{3} / \mathrm{m}^{2}\right)\end{array}$ & 0.37 & 0.48 & 0.41 & 0.41 & 0.36 & 0.4 \\
\hline $\begin{array}{l}\text { Anual water consumption } \\
\text { per user (m/3)r }\end{array}$ & 2.1 & 2.6 & 2.3 & 2.3 & 2.1 & 2.3 \\
\hline $\begin{array}{l}\text { Daily water consumption } \\
\text { per user (l/user) }\end{array}$ & 5.7 & 7.2 & 6.4 & 6.3 & 5.6 & 6.2
\end{tabular}

The indicators of annual $\mathrm{CO}_{2}$ emissions $(\mathrm{t})$ and the annual $\mathrm{CO}_{2}$ emissions per user associated with the consumption of water are quantified below.

Table 6. Annual emissions of $\mathrm{CO}_{2}$ and annual $\mathrm{CO}_{2}$ emissions per user associated with the consumption of water for 5 years. Source:

\begin{tabular}{lcccccc}
\multicolumn{7}{c}{ internal document. } \\
\hline & 2013 & 2012 & 2011 & 2010 & 2009 & Average \\
\hline Annual $\mathrm{CO}_{2}$ emissions (t) & 2.4 & 3.0 & 2.6 & 2.5 & 2.2 & 2.5 \\
Annual $\mathrm{CO}_{2}$ emissions per user (kg/user) & 2.1 & 2.6 & 2.3 & 2.3 & 2.0 & 2.3 \\
\hline
\end{tabular}

Indicators of annual water consumption bill, annual water consumption per user bill and water prices per consumed volume are detailed below. 
Table 7. Indicators of annual water consumption bill, annual water consumption per user bill and water prices per consumed volume for 5 years. Source: internal document.

\begin{tabular}{lcccccc}
\hline & 2013 & 2012 & 2011 & 2010 & 2009 & Average \\
\hline Annual water bill $(€)$ & 5,199 & 6,476 & 5,387 & 5,249 & 5,168 & 5,496 \\
\hline $\begin{array}{l}\text { Annual water consumption } \\
\text { per user bill (€/user) }\end{array}$ & 4.5 & 5.6 & 4.8 & 4.8 & 4.7 & 4.9 \\
\hline $\begin{array}{l}\text { Water prices per } \\
\text { consumed volume }\left(€ / \mathrm{m}^{3}\right)\end{array}$ & 2.16 & 2.14 & 2.09 & 2.07 & 2.31 & 2.2 \\
\hline
\end{tabular}

Finally a distribution of consumption and economic cost between uses of the school is established.

\begin{tabular}{|c|c|c|c|}
\hline & $\begin{array}{c}\text { Annual } \\
\text { consumption }\left(\mathrm{m}^{3}\right)\end{array}$ & $\begin{array}{l}\text { Water annual } \\
\text { bill }(€)\end{array}$ & Percentage \\
\hline Toilets & 1,937 & 4,165 & 76 \\
\hline Washbasin & 406 & 872 & 16 \\
\hline Kitchen & 80 & 171 & 3 \\
\hline Cleaning & 72 & 155 & 3 \\
\hline Others & 61 & 132 & 2 \\
\hline TOTAL & 2,556 & 5,496 & 100 \\
\hline
\end{tabular}

Proposal 1: Implement an "environmental water audit" at the school.

Proposal 2: Implement a counterweight in toilets with a high wall-mounted cistern.

Proposal 3: Replace all the non-timed faucets by timed faucets.

Proposal 4: Implement an aerator in the existing timed faucets.

Proposal 5: Replace the shaft of all timed faucets by an off-in-6-seconds valve.

\section{Technical description of proposals}

\section{Proposal 1}

Water consumption depends, among other factors, on consumer habits adopted by educational institution users.

Despite many efficiency measures which are located in the installation, an improper or wasteful use of available resources, in this case the water, can involve a reduced impact of the measures taken. Therefore, implementing a water audit scheme in the educational center is proposed as a first step for the rational use of water.

\section{Proposal 2}

The counterweight is a mechanism which automatically closes the water outlet to the toilet cistern. These tanks are placed above 1.5 meters on the wall, which depending on the type of toilet tank, is known as a high wall-mounted cistern. Water discharge occurs by pulling a chain. Once triggered, the emptying of the tank begins, and it does not stop until it empties completely.

In the absence of urinals in the men's toilets and in all female toilets, the discharge of water that each type of use needs (urination and defecation), one cannot differentiate at a high wall-mounted cistern with double push systems as in the 'waist-high' flush built toilets.

Instead of replacing all tanks with other smaller-capacity tanks, with such a costly initial investment, it has been decided to propose the inclusion in the mechanism in the cistern of a counterweight that makes the water stop flowing into the toilet when the chain is released. Thus the user has the ability to regulate the water used according to need, with the advantage that water consumption stops when the user decides. 


\section{Proposal 3}

It is proposed to change the non-timed faucets, which could remain opened. The savings from this substitution is difficult to quantify because it depends exclusively on the good use made of the facility. So it is considered that the time that the faucets are open for every use is 20 seconds. However, a faucet remaining open overnight (10 hours) would mean $10 \%$ of the annual consumption of that faucet.

\section{Proposal 4}

It is intended to incorporate an aerator mechanism- flow limiter with spray function into existing timed faucets, providing a supply similar to a bathroom shower with 20 high pressure flows, allowing hand washing. It provides adequate comfort and reduces the water flow rate to 2.5 liters per minute at a pressure of 3.5 bars.

\section{Proposal 5}

Current timed faucets have an opening time of 8,10 and 12 seconds respectively.

This proposal aims to replace all existing faucets for timed faucets that close after 6 seconds.

In this way the water consumption is reduced due to the time elapsed from the faucet stopping until it is finally closed. To completely eliminate this period, electronic faucets could be installed, but the cost of the initial investment and maintenance of the equipment would be greater, which could be prohibitive for an educational establishment.

\section{Calculation of consumption and cost before the implementation of proposals}

Proposal 1: This proposal concerns the entire water consumption of the school, an annual water consumption of 2,556 $\mathrm{m}^{3}$ per year at a cost of $€ 5,520.96$.

Proposal 2: This proposal concerns the consumption of water in the toilets with high wall-mounted cistern, an annual water consumption of $1,705 \mathrm{~m}^{3}$ per year at a cost of $€ 3,682.80$.

Proposal 3: This proposal concerns the consumption of water in the wash basins without timed faucets, an annual water consumption of $83 \mathrm{~m}^{3}$ per year at a cost of $€ 179.28$.

Proposals 4 and 5: These proposals concern the consumption of water in the wash basins with timed faucets, an annual water consumption of $323 \mathrm{~m}^{3}$ per year at a cost of $€ 697.68$.

\section{Calculation of the reduction in consumption of water and economic savings account for proposals}

Proposal 1: If an overly ambitious target of average consumption in schools is not set, this proposal would entail a reduction of $24.7 \%$ of water consumption. It would save $631 \mathrm{~m}^{3}$ of water per year, which would mean a saving of $€$ $1,362.96$

Proposal 2: Average consumption of high wall-mounted cistern toilets is estimated at 5 liters per flush after implantation against 10.4 liters per current download. It would save $816 \mathrm{~m}^{3}$ of water per year, which would mean a saving of $€ 1,762.56$.

Proposal 3: Considering non-timed faucets are opened for 20 seconds for each use. If the faucets close at 6 seconds, this would mean a reduction of $70 \%$ in consumption. Additionally, new faucets incorporate aerators described in proposal No. 4, which are able to decrease the average flow rate of 14 liters per minute to 2.5 liters per minute. This would mean a further reduction in consumption of $82 \%$. The combined effect of both measures would reduce consumption $95 \%$. It would save $79 \mathrm{~m}^{3}$ of water per year, which would mean a saving of $€ 170.64$.

Proposal 4: If the same is done using timer faucets, by decreasing the average flow rate of 6.1 liters per minute to 2.5 liters per minute, a reduction of $59 \%$ in water consumption would be obtained. It would save $191 \mathrm{~m}^{3}$ of water per year, which would mean a saving of $€ 412.56$. 
Proposal 5: The average opening time of timed faucets is 10.9 seconds. If the faucets close at 6 seconds, this would mean a reduction of $45 \%$ in consumption. It would save $145 \mathrm{~m}^{3}$ of water per year, which would mean a saving of $€$ 313.20 .

\section{Calculation of environmental benefit of proposals $\left(\mathrm{CO}_{2}\right.$ emissions)}

Emissions associated with the consumption of water is $0.993 \mathrm{~kg}$ of $\mathrm{CO}_{2}$ per $\mathrm{m}^{3}$. The $\mathrm{CO}_{2}$ emission reductions obtained by the proposals are:

Proposal 1: $0.6 \mathrm{t} \mathrm{CO}_{2}$.

Proposal 2: $0.8 \mathrm{t} \mathrm{CO}_{2}$.

Proposal 3: $0.1 \mathrm{t} \mathrm{CO}_{2}$.

Proposal 4: $0.2 \mathrm{t} \mathrm{CO}_{2}$.

Proposal 5: $0.1 \mathrm{t} \mathrm{CO}_{2}$.

\section{Economic investment necessary to undertake proposals}

Proposal 1: Since this is a school, the implementation of this proposal is framed within the center's activity, so there is no need to spend any additional economic resources.

Proposal 2: A counterweight is charged at $€ 14.52$ per unit. Its installation can be carried out by the center's maintenance service, so there would not be a cost increase. Its implementation in total for the 66 high wall-mounted cisterns would involve an investment of $€ 958.32$.

Proposal 3: A timed faucet costs $€ 47.80$ per unit. Labour for replacing each faucet would cost $€ 14.50$. Substitution of the 11 non-timed faucets would involve an investment of $€ 685.3$.

Proposal 4: An aerator with the features described costs $€ 10.54$ per unit. Its installation can be carried out by the center's maintenance service, so there would not be a cost increase. Its implementation in total for the 43 timed faucets would mean an investment of $€ 453.22$.

Proposal 5: The off-in-6-seconds faucet costs $€ 20.39$ per unit. Faucet substitution could be carried out by the center's maintenance service, so it would not have additional labour costs. The replacement of the 43 timed faucets would involve an investment of $€ 876.77$.

\section{Period of simple payback on investments}

The simple payback period of investment is obtained by dividing the economic investment to be made between the savings achieved with each proposal.

Proposal 1: None.

Proposal 2: 0.5 years.

Proposal 3: 4.0 years.

Proposal 4: 1.1 years.

Proposal 5: 2.8 years.

\section{Economic analysis of proposals}

Proposal 1: Total savings after 10 years amounts to $€ 13,630$. 
Figure 3. Graph of improvement proposal 1. Source: internal document.

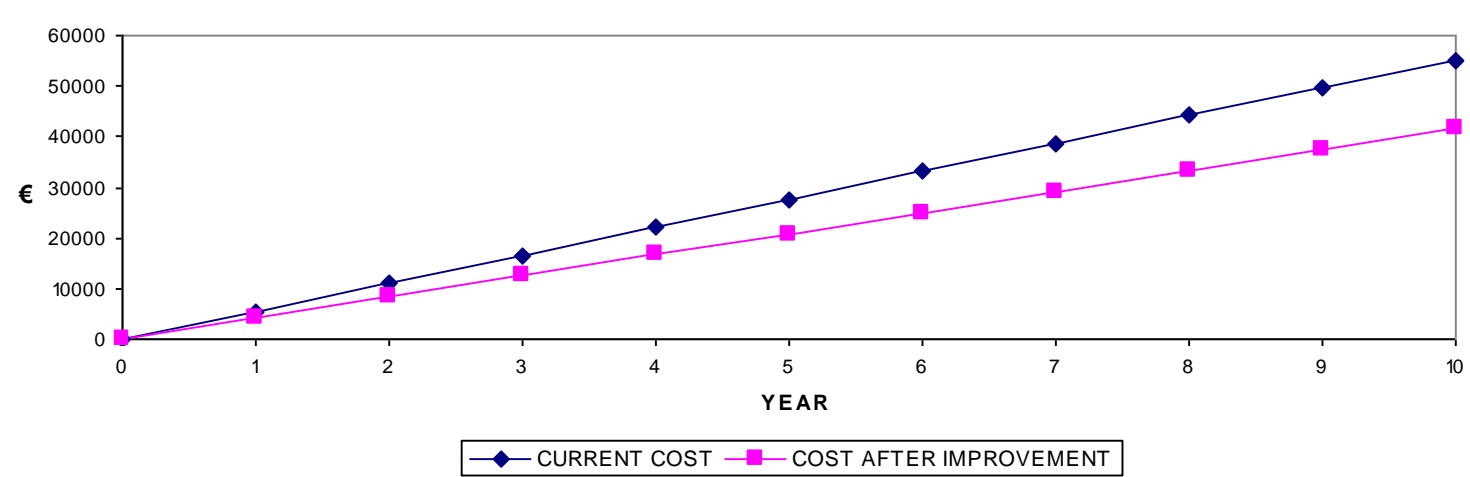

IMPROVEMENT PROPOSAL 1.

Proposal 2: Total savings after 10 years amounts to $€ 16,667$.

Figure 4. Graph of improvement proposal 2. Source: internal document.

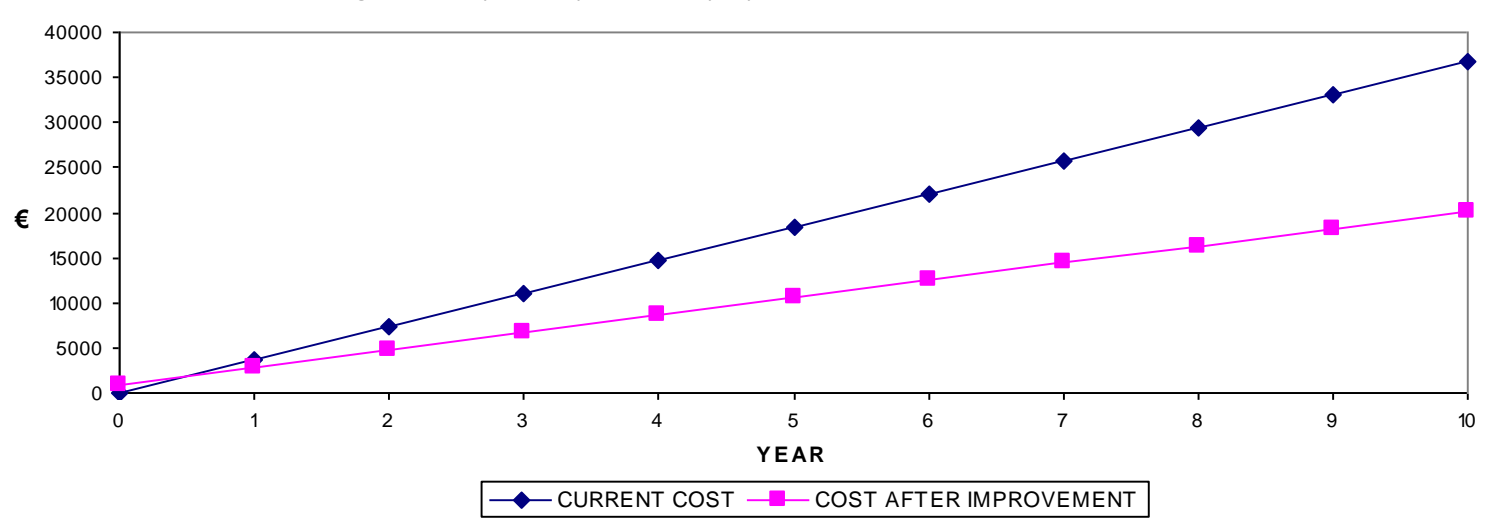

IMPROVEMENT PROPOSAL 2.

Proposal 3: Total savings after 10 years amounts to $€ 1,021$.

Figure 5. Graph of improvement proposal 3. Source: internal document.

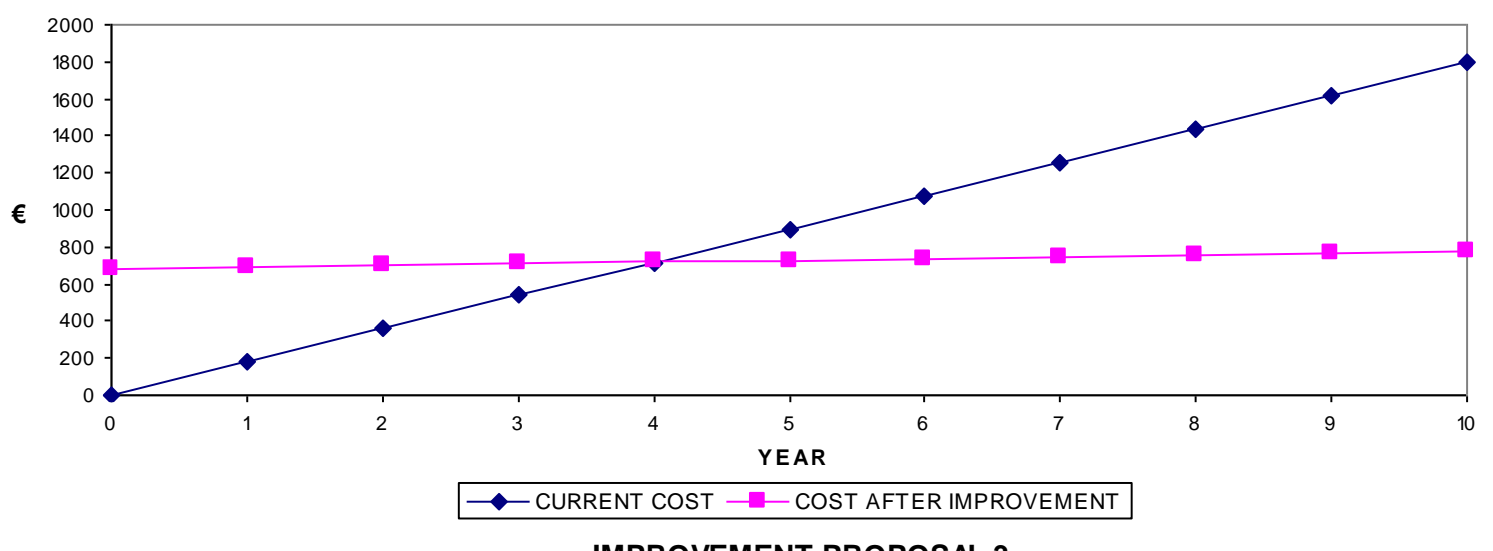

IMPROVEMENT PROPOSAL 3.

Proposal 4: Total savings after 10 years amounts to $€ 3,672$. 
Figure 6. Graph of improvement proposal 4. Source: internal document.

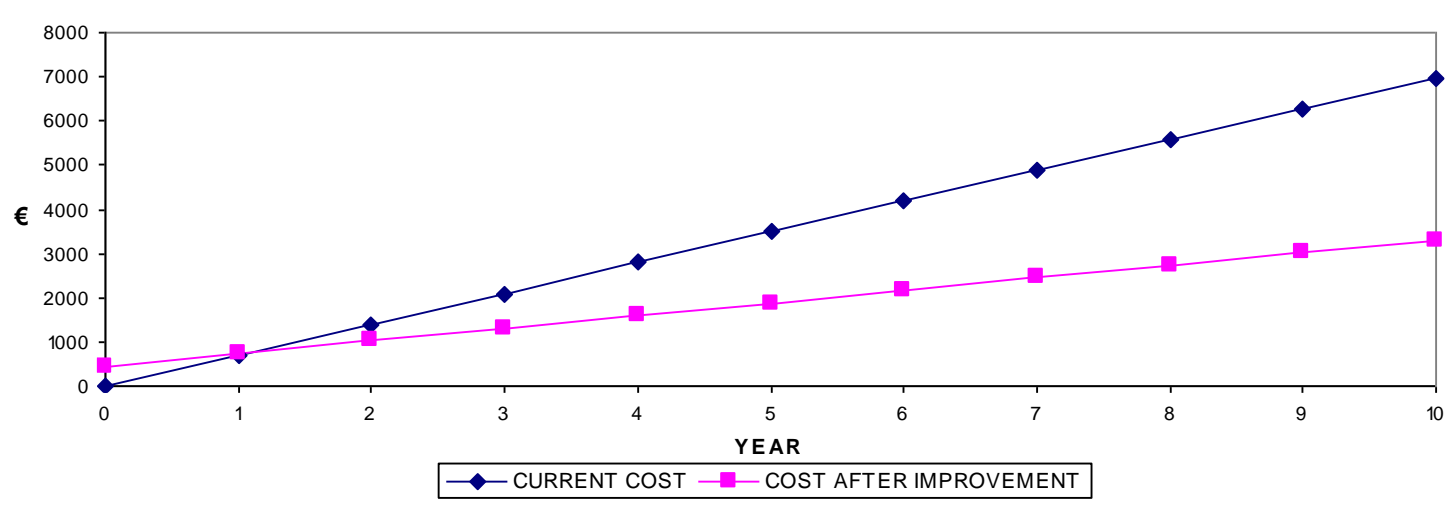

IMPROVEMENT PROPOSAL 4.

Proposal 5: Total savings after 10 years amounts to $€ 2,255$.

Figure 7. Graph of improvement proposal 5. Source: internal document.

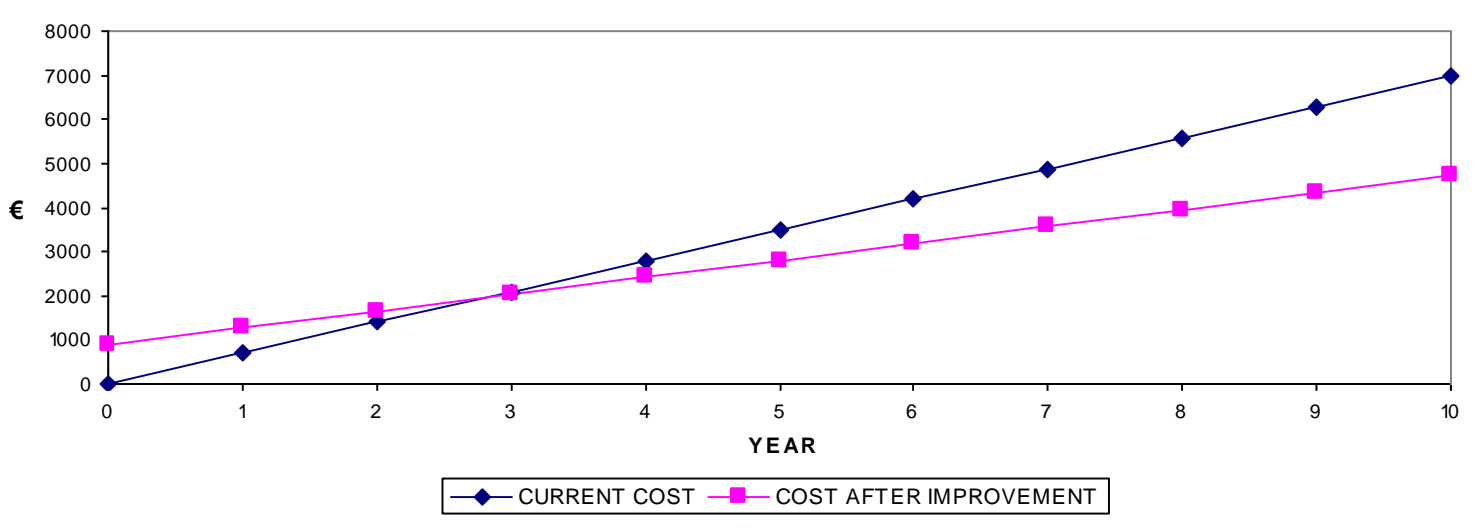

IMPROVEMENT PROPOSAL 5.

Discussion of Results

The average water consumption in schools in Spain is 5 liters per day per user (Barón \& González, 2003). The school consumes $24.7 \%$ more water than average. With these data it is questionable that the use of water that is being made in the educational institution is liable to be optimized.

The water used in toilets and sinks represents $92 \%$ of total water consumption in the building. Since the use of kitchen, cleaning and others represent together one half of the consumption of the use of washbasins, any saving proposal for these uses will have little impact on the overall consumption so their study is rejected.

Regardless of quantifiable results, it is recommended to adopt the proposal on the replacement of non-timed faucets by timed faucets to eliminate the undesirable effects of a faucet remaining open, either accidentally or intentionally. If the maintenance service is capable of replacing the faucets no additional cost to the center is incurred, therefore the simple payback period on investment and total savings after 10 years would be improved.

\section{Conclusions}

If we analyze the improvements proposed from the point of view of investment, we obtain the following data: proposal 1: free, proposal 2: $€ 958.32$, proposal 3: $€ 685.3$, proposal 4: $€ 453.22$, proposal 5: $€ 876.77$. These values assume a lower investment than necessary for the implementation of proposals to reduce consumption of electricity and heating.

If we analyze the proposals for improvement from the standpoint of the simple payback period on investment, we obtain the following information: proposal 1: none, proposal 2: 0.5 years, proposal 3: 4.0 years, proposal 4: 1.1 years, proposal 5: 2.8 years. These values assume that the payback is obtained after a short period; which appeals to the manager of the building for adopting the proposed issues. 
If we analyze the improvements proposed from the point of view of the environmental benefit from $\mathrm{CO}_{2}$ emissions avoided, we obtain the following information: proposal 1: $0.6 \mathrm{t} \mathrm{CO}_{2}$, proposal 2: $0.8 \mathrm{t} \mathrm{CO}_{2}$, proposal 3: $0.1 \mathrm{t} \mathrm{CO}_{2}$, proposal 4: $0.2 \mathrm{t} \mathrm{CO}_{2}$, proposal 5: $0.1 \mathrm{t} \mathrm{CO}_{2}$. The first two proposals obtain a significant reduction in emissions versus the values of the last three steps, which are more modest.

Finally, the improvements proposed are ordered from the point of view of the investment required for their implementation in relation to the savings obtained after 10 years. This criterion is used to order the performance of the proposals if it seeking differences in time after the implementation process. The order of implementation of the resulting proposals is as follows: $1,2,4,5$ and 3.

After this work, it can be concluded that the incorporation of the study into water consumption in the process of an energy audit in schools is relevant in the light of the improvements proposed with little investment, as they achieve short, simple payback periods from these investments as well as helping to reduce energy consumption in the country.

References

Arco, J., Sánchez, J., Saucedo, R., Gil, F., Salmerón, J. M., \& Molina J. L. (2013). Gestión y rehabilitación energética de edificios existentes: procedimiento experimental de diagnosis y caracterización energética. Revista de la Construcción, 12(3), 9-16. doi: 10.4067/S0718$915 \times 2013000300001$

Arrojo, P. (2013). Crisis global del agua en el "planeta agua". Éxodo, 120, 25-33.

Barón, A., \& González, C. (2003). La ecoauditoría del agua en tu centro educativo. Guía para el profesorado. Palma de Mallorca: Fundación Ecología y Desarrollo.

Cabrera, E., Pardo, M. A., Cabrera, E. Jr., \& Cobacho, R. (2010). Agua y energía en España. Un reto complejo y fascinante. Ingeniería del Agua, 17(3), 235-246.

Centro Mario Molina. (2011). Evaluación energética de los actuales sistemas de aguas urbanas y propuestas de manejo de los recursos hídricos en la ciudad de México. Retrieved from http://centromariomolina.org/wp-content/uploads/2012/05/12.Evaluaci\%C3\%B3nEnergeticaAguasUrbanasDF_fin.pdf

California Energy Commission. (2006). Refining estimates of waterrelated energy use in California. Retrieved from http:// www.energy.ca.gov/2006publications/CEC-500-2006-118/CEC-500-2006-118.PDF

Evans, J. M., \& Schiller, S. (2007). Procedimientos de auditorías y evaluación de servicio energético: desarrollo, aplicación y transferencia. Avances en Energías Renovables y Medio Ambiente, 11, 07.17-07.22.

Gómez, E., Cabrera, E., Balaguer, M., \& Soriano, J (2015). Direct and indirect water supply: an energy assessment. Procedia Engineering, 119, 10881097.

Granero, A., \& García, R. (2013). La forma de la arquitectura y el equilibrio energético. Buenos Aires: Croquis.

Hardi, L. \& Garrido, A. (2010). Análisis y evaluación de las relaciones entre el agua y la energía en España. Retrieved from http://www.fundacionbotin.org/89dguuytdfr276ed_uploads/Observatorio\%20Tendencias/PUBLICACIONES/MONOG R AFIAS/PAV/PAV6.pdf

Kenway S., McMahon J., Elmer V., Conrad S., \& Rosenblum J. (2013). Managing water-related energy in future cities - a research and policy roadmap. Journal of Water and Climate Change, 4 (3), 161-175. doi: 10.2166/wcc.2013.063

Martín, L. (2014). Reducir el consumo de energía mediante un uso sostenible del agua. Agua y energía, un binomio indisoluble (pp. 64-66). Madrid: Grupo Tecma Red.

Martínez, F. J. (2011). Estudio de la huella energética del abastecimiento urbano de agua de la provincia de Almería. Retrieved from http://repositorio.ual.es/bitstream/handle/10835/1152/Estudio\%20de\%20la\%20Huella\%20Energetica\%20 del\%20Abastecimiento\%20Urbano\%20de\%20Agua\%20de\%2Ola\%2OProvincia\%20de\%20Almeria_Martinez\%20Rodriguez\%2c\%20Francisco\%20 Javier.pdf?sequence $=1 \&$ isAllowed $=y$

Ministerio de Industria, Energía y Turismo \& Ministerio de Fomento (2014). Factores de emisión de $\mathrm{CO}_{2}$ y coeficientes de paso a energía primaria de diferentes fuentes de energía final consumidas en el sector de edificios en España. Retrieved from http://www.minetad.gob.es/energia/desarrollo/EficienciaEnergetica/RITE/Reconocidos/Reconocidos/otros \%20documentos/Factores_emision_CO2.pdf

Parlamento Europeo (2012). Directiva 2012/27/UE, del Parlamento Europeo y del Consejo, de 25 de octubre de 2012, relativa a la eficiencia energética. Retrieved from https://www.boe.es/doue/2012/315/L00001-00056.pdf

Plappally, A. K. \& Lienhard, J. H. (2012). Energy requirements for water production, treatment, end use, reclamation, and disposal. Renewable and Sustainable Energy Reviews, 16, (7), 4818-4848. doi: 10.1016/j.rser.2012.05.022

Scott C.A., Crootof A., \& Kelly-Richards S. (2016). Hettiarachchi H., Ardakanian R. (Eds.), The Urban Water-Energy Nexus: Building Resilience for Global Change in the "Urban Century" (pp. 113-140). Cham: Springer.

Venkatesh, G. \& Brattebø, H. (2011) Energy consumption, costs and environmental impacts for urban water cycle services: Case study of Oslo (Norway). Energy, 36, (2), 792-800. doi: 10.1016/j.energy.2010.12.040. 